\title{
Does Foreign Direct Investment Matter Anymore?
}

\author{
John C. Edmunds ${ }^{1}$ \& Gaofeng Zou ${ }^{2}$ \\ ${ }^{1}$ Babson College, Wellesley, Massachusetts USA \\ ${ }^{2}$ College of Management and Economics, Tianjin University, Tianjin, China. Support from The National Natural \\ Science Foundation of China \\ Correspondence: John C. Edmunds, Babson College, Wellesley, Massachusetts, USA
}

Received: August 27, 2015

doi:10.11114/aef.v2i4.1099
Accepted: September 14, $2015 \quad$ Available online: September 21, 2015

URL: http://dx.doi.org/10.11114/aef.v2i4.1099

\begin{abstract}
Although Foreign Direct Investment (FDI) is widely believed to raise the receiving country's economic growth, the statistical evidence to support that belief is weak. The macro-level data portray a mixed set of results. FDI neither raises nor lowers a country's economic growth in the time range from the year when the FDI comes in to three years after it arrives. There are many possible explanations why the data show such a weak association between FDI and economic growth. These include reasons why the data do not show the benefit, even though the benefit exists; and reasons why FDI might not raise a country's economic growth. In the data that we examined, increases in a country's national stock market capitalization were more positively associated with the country's subsequent economic growth.
\end{abstract}

Keywords: foreign direct investment, international finance, economic development

JEL Classification: F21, F3

\section{Introduction and Overview}

The debate about foreign direct investment (FDI) has been going on for centuries. Advocates have extolled FDI's transfers of technology and its power to create new export industries from scratch. Detractors point to FDI that created enclaves to exploit host countries' natural resources, and did little to forge linkages with other parts of the host countries' economies. FDI was either a jolt of adrenaline or a cruel deception.

We examined macroeconomic data to assess how big the influence of FDI has been on host countries' subsequent economic growth. We expected to find that FDI played a major role -- either in raising host countries' GDP growth rates, or in increasing and transforming the composition of host countries' exports, or in both. We found very little that indicates strong efficacy to FDI. This was not completely surprising, because there are many possible distortions in the economic statistics. Those could easily have concealed a positive or a negative effect.

\section{The Historical Debate}

Extensive theoretical and empirical research has focused on various explanations of firms' international involvement. A selected list from Morgan and Katsikeas (1997) of classic theories of trade and foreign direct investment is presented in Table 1. Notably, the first explanations of foreign direct investment have attempted to address the limitations of the early international trade theories, such as the classic trade theory (Ricardo, 1817, and Smith 1776), the factor production theory (Hecksher and Ohlin, 1933), and the product life cycle theory (Vernon, 1966, 1971 and Wells, 1968, 1969). However, as the globalization trend has gained momentum, theorists have concentrated on more specialized foreign investment frameworks, such as the market imperfections theory (Hymer, 1970), the international production theory (Dunning, 1980 and Fayerweather, 1982), and the internationalization theory (Buckley, 1982, 1988 and Buckley and Casson, 1976, 1985).

Table 1. Theories of International Trade and Investment

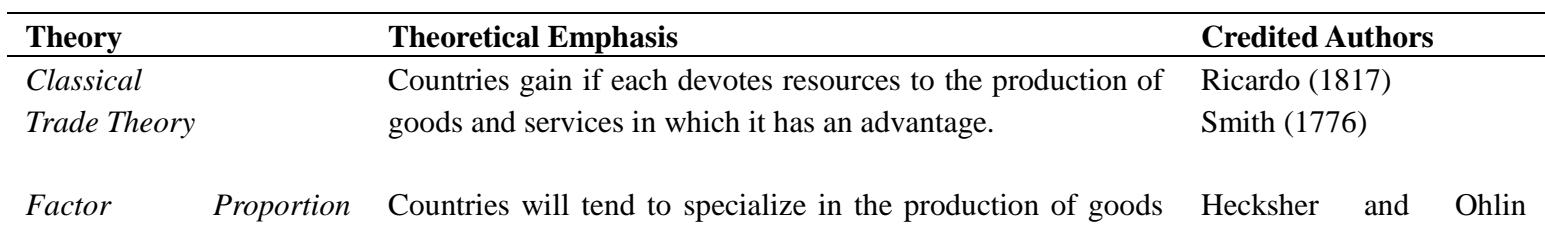


Theory and services that utilize their most abundant resources.

Product The cycle follows that: a country's export strength builds;

Life Cycle Theory

Market Imperfection
Theory

International Production Theory

Internationalization Theory foreign production starts; foreign production becomes competitive in export markets; and import competition emerges in the country's home market.

The firm's decision to invest overseas is explained as a strategy to capitalize on certain capabilities not shared by competitors in foreign countries.

The propensity of a firm to initiate foreign production will depend on the specific attractions of its home country compared with resource implications and advantages of locating in another country.

Internationalization concerns extending the direct operations of the firm and bridging under common ownership and control the activities conducted by intermediate markets that link the firm to customers. Firms will gain in creating their own internal market such that transactions can be carried out at a lower cost within the firm.
(1933)

Vernon $(1966,1971)$

Wells $(1968,1969)$

Hymer (1970)

Dunning (1980)

Fayerweather (1982)

Buckley (1982, 1988)

Buckley and Casson

(1976, 1985)

Source: Morgan and Katsikeas (1997)

Shaked (1986) states, "The 'true' MNC is, after all, presumed to maximize net gains internationally." This search for profit is a result of perceived opportunities based on transaction cost theory, market power consideration, and location advantages. The two issues that arise from this statement are argued along two strands of literature. The first strand assumes that market inefficiencies exist and that opportunities can be sought through FDI. The second strand argues that markets are efficient, and it is up to shareholders to realize diversification benefits by investing in a diversified portfolio of assets.

In the real world of market imperfections (Kindleberger, 1969 and Hymer, 1976) firms can choose between a variety of foreign market entry modes, e.g. wholly-owned subsidiaries, joint-ventures, licensing, and other contractual agreements. Examples of market imperfections include government regulations and controls, such as tariffs and capital controls that impose barriers to free trade and private portfolio investments. Market failures also exist in the areas of firm-specific skills and information (Shapiro, 1992). The theory of the multinational corporation, as set forth by Shapiro (1992) amongst others, considers the international expansion of companies as a means of using intangible capital to penetrate foreign markets. The nature of intangible capital determines the form of international involvement; thus, if the intangible assets are in the form of trademarks, patents, or organizational abilities that can be embodied in products without adaptation, the firm would chose licensing or exporting as the foreign market entry modes, whereas if the intangible capital consists of organizational skills pertaining to the firm itself, the company will become involved internationally by establishing foreign subsidiaries.

Reeb, Kwok, and Baek (1998) argue that systematic risk may increase in the process of globalization through exchange rate risk, political risk, the agency problem, asymmetrical information, and manager's self-fulfilling prophecies. Kwok and Reeb (2000) add to the conclusion that internationalization may increase the systematic risk of the firm by suggesting an upstream-downstream hypothesis, arguing that when firms from stable economies make international investments, it increases risk and leads to a reduction in debt usage. On the other hand, when firms from weaker economies make international investments, it decreases their risk and allows for greater debt utilization. The idea behind this effect has to do with characteristics of each type of economy. For example, emerging market projects have potentially greater infrastructure risks, customer risks, banking system and payments risks, labor risks and political risks. Infrastructure risks are risks associated with the infrastructure of the country, such as the development of the transportation systems, telephone systems, and power systems within a country. Transportation delays, communication delays, and power outages are some of the effects of infrastructure risk. Labor risk relates to differences in health care, education, and living conditions for employees. Volatility in workforce performance and absenteeism are results of labor risk. These additional risks of less stable economies explain the overall impact of internationalization on firm risk and leverage.

In addition, several variables affect the location decision for foreign direct investment. These factors include: market size and growth potential; tariff and non-tariff barriers to trade; labor and other input costs; as well as legal, political, 
and economic conditions. The "psychic distance" strategy is a way to minimize the risks that arise from unfamiliarity of a host market. In this case the firm invests in a country that is as similar as possible to the home country. The psychic distance theory is based on the idea that entering countries that are psychically close will reduce the overall uncertainty that firms face when entering a new market. (Johanson and Vahlne, 1992) While there are few variations of the psychic distance, O'Grady and Lane (1996) use the following indicators: the level of economic development in the importing countries, the difference in the level of development between the countries, the difference in the level of education in the importing countries, the difference in "business," cultural, and local languages, the existence of previous trading channels, and other business factors such as industry structure, competitive environment, and cultural difference. The Psychic Distance Paradox by O'Grady and Lane (1996) challenged the decision for firms to locate in countries that are "psychically" close if they ignore other important variables. They argue that the failure might lie in the managers' inability to account for differences between two countries, such as the United States and Canada. The psychic distance paradox is that "familiarity may breed carelessness." (O'Grady and Lane, 1996)

Davidson (1980) looks at factors including prior experience in a host country and the experience level of the firm. Davidson explains his observations in terms of an experience curve effect: "The presence of an existing subsidiary in a foreign market will increase the firm's propensity to make subsequent investments in that market." (Davidson, 1980) The theory of clusters as set forth by Porter (1998) further attempts to explain the location decision. Clusters reveal that the business environment directly outside the office plays an important role in the business. Peters and Hood (2000) argue that the cluster approach proposed by Porter and used by governments in their industrial planning process raises concerns regarding the identification and selection of clusters and the assessment and relevance of cluster needs. The authors consider this approach to be a top-down approach; instead, they suggest that a bottom-up approach would be more valuable. The bottom-up approach should be based on strategic initiatives, such as maximizing backward and forward linkages, leading to higher level of employment, creating maximum value added, and generating technological transformation.

All of the theories work to form the foundation for studies related to particular issues, such as the benefits of globalization for companies pursuing international expansion. Growing international linkages through FDI are an important feature of financial globalization and raise important challenges for policymakers and statisticians in industrial and developing countries alike. (IMF, 2003) The United Nations Conference on Trade and Development (UNCTAD) has reported increasing uniformity in terms of investment frameworks governing FDI. Additionally, fiscal regimes, land and labor laws, competition polices, residence permits and intellectual property rights are changing in favor of FDI. These changes have been in place over ten years, for example in 2002, 236 favorable laws were enacted in 70 countries in favor of FDI. The next section explains our data and presents summary statistics.

\subsection{The Data}

The data we used came primarily from the World Bank database ${ }^{1}$. We also used time series data from the United Nations Conference on Trade and Development (UNCTAD) ${ }^{2}$ for the index of export concentration of each country's exports. Data for the index from that source did not start until 1995 and for that reason it gave inconclusive results. For a majority of the countries, time series data for GDP growth starts in 1961, while time series data for FDI as a percentage of GDP starts in 1970. Time series data for exports as a percentage of GDP starts in 1960. Data for foreign portfolio investment as a percentage of GDP, also from the World Bank database, starts later, in 2005 and is less complete. Data for stock market capitalization as a percentage of GDP starts in 1988 for some of the countries we studied.

We selected 33 countries, all middle-income or high income. These are Australia, Belgium, Brazil, Bulgaria, Chile, China, Finland, France, Germany, Hungary, India, Indonesia, Japan, Latvia, Lithuania, Malaysia, Mexico, Netherlands, New Zealand, Pakistan, Peru, Philippines, Poland, Romania, Russia, Saudi Arabia, Singapore, South Africa, Switzerland, Thailand, Turkey, U.K. and Ukraine. The majority is middle income emerging, and all have stock market data.

We do not assert that the 33 countries we selected are representative of all the countries in the world. We selected the 33 because they are big, or because the data were complete enough to allow us to analyze the possible relationships between their macroeconomic variables. Tables 2 and 3 are the complete Excel sheet with the data and with our results. These results are also posted on the author's website.

\footnotetext{
${ }^{1}$ http://data.worldbank.org

2 http:// unctadstat.unctad.org
} 
Table 2. Results

\begin{tabular}{|c|c|c|c|c|c|c|c|c|c|c|c|c|c|}
\hline & [1a] & [1b] & [1c] & [2a] & [2b] & {$[2 c]$} & [3a] & [3b] & {$[3 c]$} & [4a] & [4b] & [5a] & [5b] \\
\hline \multirow[t]{2}{*}{ Australia } & 7 & 7 & 7 & 7 & 7 & 7 & 7 & 7 & 7 & 24 & 24 & 21 & 21 \\
\hline & -1.0546 & 0.5289 & -0.6513 & 0.1668 & -1.0906 & -0.5568 & -1.2572 & 2.1465 & 0.1782 & 0.4171 & 0.0094 & -0.9932 & 1.0628 \\
\hline \multirow[t]{2}{*}{ Belgium } & 8 & 8 & 8 & 8 & 8 & 8 & 8 & 8 & 8 & 11 & 11 & 11 & 11 \\
\hline & -0.7411 & -0.9195 & 1.5184 & -0.7924 & -0.3107 & 1.2346 & 2.993 & 4.5236 & 4.1116 & 1.2326 & 1.8268 & 0.9342 & 1.7718 \\
\hline \multirow[t]{2}{*}{ Brazil } & 8 & 8 & 8 & 8 & 8 & 8 & 8 & 8 & 8 & 25 & 25 & 22 & 22 \\
\hline & -0.0754 & 0.6220 & 0.1281 & 0.0232 & -0.0679 & 0.4371 & 0.3941 & -2.2278 & -0.4551 & -0.3913 & 2.4548 & 0.6794 & 1.7737 \\
\hline \multirow[t]{2}{*}{ Bulgaria } & 8 & 8 & 8 & 8 & 8 & 8 & 8 & 8 & 8 & 18 & 18 & 15 & 15 \\
\hline & 1.6398 & 0.5233 & -0.0017 & 1.5972 & 0.4448 & 0.9184 & 1.3003 & -0.1639 & 1.1053 & 1.932 & -0.9204 & 1.8125 & 1.8446 \\
\hline \multirow[t]{2}{*}{ Chile } & 8 & 8 & 8 & 8 & 8 & 8 & 8 & 8 & 8 & 25 & 25 & 22 & 22 \\
\hline & 0.0807 & -0.2178 & -0.0505 & -0.0746 & 2.8251 & 0.9323 & -0.5559 & 0.4730 & -0.0060 & -2.3403 & -0.0465 & -0.6091 & -0.6228 \\
\hline \multirow[t]{2}{*}{ China } & 8 & 8 & 8 & 8 & 8 & 8 & 8 & 8 & 8 & 22 & 22 & 19 & 19 \\
\hline & 0.6402 & 0.7518 & 2.3694 & 0.1041 & -0.1121 & 0.9052 & 0.0653 & -0.2074 & 1.8597 & 2.4273 & 0.9846 & 1.9671 & 1.6001 \\
\hline \multirow[t]{2}{*}{ Finland } & 8 & 8 & 8 & 8 & 8 & 8 & 8 & 8 & 8 & 25 & 25 & 22 & 22 \\
\hline & -1.7034 & -1.9215 & 3.6774 & .5156 & 0.0823 & 1.6963 & 0.227 & -0.0065 & 1.4913 & 1.5948 & 0.9518 & 1.1398 & 1.8275 \\
\hline \multirow[t]{2}{*}{ France } & 8 & 8 & 8 & 8 & 8 & 8 & 8 & 8 & 8 & 25 & 25 & 22 & 22 \\
\hline & 1.301 & -0.6912 & 0.5864 & -0.9161 & 1.8257 & 1.7803 & 0.3225 & -0.156 & 1.1195 & 0.3342 & -0.172 & -0.2625 & 0.2824 \\
\hline \multirow[t]{2}{*}{ Germany } & 8 & 8 & 8 & 8 & 8 & 8 & 8 & 8 & 8 & 25 & 25 & 22 & 22 \\
\hline & -0.3377 & -2.0028 & -0.8282 & -0.9389 & 0.9273 & 1.2212 & 0.5066 & -0.7277 & 1.6553 & 0.4706 & -0.5005 & -0.348 & -0.228 \\
\hline Hungary & 8 & 8 & 8 & 8 & 8 & 8 & 8 & 8 & 8 & 22 & 22 & 19 & 19 \\
\hline & 1.6773 & -1.4835 & -0.8908 & 0.8111 & 0.4985 & -0.2551 & 1.2691 & -0.7915 & 0.8978 & -0.2004 & 2.5392 & 1.1597 & 2.3963 \\
\hline India & 7 & 7 & 7 & 7 & 7 & 7 & 7 & 7 & 7 & 24 & 24 & 21 & 21 \\
\hline & -1.712 & 0.1704 & 2.2156 & 0.207 & 0.2555 & 0.8057 & 3.5299 & -1.9536 & 2.3412 & -1.6982 & 3.7705 & 0.8504 & 1.4402 \\
\hline Indonesia & 8 & 8 & 8 & 8 & 8 & 8 & 8 & 8 & 8 & 25 & 25 & 22 & 22 \\
\hline & -1.2182 & 1.4354 & 0.1592 & 0.4444 & -2.0161 & 1.9815 & 0.1133 & 0.8876 & 1.5343 & 2.2409 & -1.1916 & 2.0303 & -0.6978 \\
\hline Japan & 7 & 7 & 7 & 7 & 7 & 7 & 7 & 7 & 7 & 24 & 24 & 21 & 21 \\
\hline & 0.6416 & -0.9673 & 0.0791 & -0.8236 & 0.4207 & 1.2584 & 0.4044 & -0.6219 & 1.1541 & -1.9705 & 3.0816 & -0.9756 & 3.7589 \\
\hline Latvia & 8 & 8 & 8 & 8 & 8 & 8 & 8 & 8 & 8 & 18 & 18 & 15 & 15 \\
\hline & 1.6443 & -1.842 & 5542 & 0.9312 & -1.4667 & 3.3896 & 0.5094 & 3.303 & 3.9789 & 2.8506 & 1.8303 & 0.0107 & 1.9312 \\
\hline Lithuania & 8 & 8 & 8 & 8 & 8 & 8 & 8 & 8 & 8 & 18 & 18 & 15 & 15 \\
\hline & 0.7414 & 5.0067 & -1.8847 & -0.6126 & 0.5314 & 0.5938 & 1.3402 & -0.639 & 1.6263 & 1.752 & 0.8758 & 1.4047 & 1.8799 \\
\hline Malaysia & 7 & 7 & 7 & 7 & 7 & 7 & 7 & 7 & 7 & 24 & 24 & 21 & 21 \\
\hline & -0.152 & 0.5171 & 0.4039 & 0.2277 & 0.1899 & 0.2704 & 0.9001 & -0.4984 & 2.8794 & 2.9325 & 0.317 & 3.3834 & 1.8727 \\
\hline Mexico & 8 & 8 & 8 & 8 & 8 & 8 & 8 & 8 & 8 & 25 & 25 & 22 & 22 \\
\hline & 0.3262 & -0.1852 & -0.1596 & -0.1654 & 0.4679 & 0.1524 & 1.1784 & 1.2521 & 1.0791 & 0.0082 & -0.6771 & 1.0602 & -0.5246 \\
\hline Netherlands & 8 & 8 & 8 & 8 & 8 & 8 & 8 & 8 & 8 & 25 & 25 & 22 & 22 \\
\hline & 0.5751 & 0.1538 & 1.0482 & -0.4175 & 0.4486 & 1.3601 & 0.6947 & -0.5834 & 1.2467 & 0.5533 & 0.8674 & 0.8728 & 1.2841 \\
\hline New Zealand & 7 & 7 & 7 & 7 & 7 & 7 & 7 & 7 & 7 & 23 & 23 & 21 & 21 \\
\hline & 1.3624 & 0.74 & 0.6269 & -0.0625 & 0.0045 & 0.6516 & 0.1547 & .4805 & 1.9028 & 0.6238 & 2.5561 & -0.3768 & 3.9148 \\
\hline Pakistan & 8 & 8 & 8 & 8 & 8 & 8 & 8 & 8 & 8 & 25 & 25 & 22 & 22 \\
\hline & -1.1805 & -2.8608 & 2.4936 & 1.1797 & -1.8052 & 2.9686 & 2.483 & 0.4072 & 2.8463 & -1.0927 & 2.1073 & 1.3844 & 0.884 \\
\hline Peru & 7 & 7 & 7 & 7 & 7 & 7 & 7 & 7 & 7 & 23 & 23 & 20 & 20 \\
\hline & -0.2267 & 1.5797 & 0.8066 & .5487 & -0.4172 & 0.3573 & 3398 & 0.416 & 1.1826 & 3.1522 & 1.0707 & 1.8398 & 2.2361 \\
\hline Phillipines & 8 & 8 & 8 & 8 & 8 & 8 & 8 & 8 & 8 & 25 & 25 & 22 & 22 \\
\hline & 0.5911 & 0.2688 & 0.8301 & 1.6273 & 0.4171 & 1.0655 & 0.6469 & 0.1357 & 0.4442 & -0.4418 & 1.2533 & -0.1385 & 0.3973 \\
\hline Poland & 8 & 8 & 8 & 8 & 8 & 8 & 8 & 8 & 8 & 22 & 22 & 19 & 19 \\
\hline & -1.3328 & 1.8408 & -0.2628 & 0.7999 & -0.5754 & 1.1701 & .6032 & -0.3918 & 2.1806 & 2.8519 & -0.8138 & 1.7245 & 1.2889 \\
\hline Romania & 7 & 7 & 7 & 7 & 7 & 7 & 7 & 7 & 7 & 18 & 18 & 15 & 15 \\
\hline & 1.1419 & 0.0453 & -0.5925 & -0.6678 & 2.1905 & -1.5318 & -0.6244 & 0.0377 & -0.2964 & 1.1351 & -0.1072 & 1.0874 & 1.9413 \\
\hline Russia & 8 & 8 & 8 & 8 & 8 & 8 & 8 & 8 & 8 & 21 & 21 & 19 & 19 \\
\hline & 1.0557 & 0.6742 & -0.7117 & 0.3458 & -0.2172 & 0.2355 & 0.8621 & 0.453 & 0.3905 & 0.9989 & 1.1861 & 1.8948 & 1.131 \\
\hline Saudi Arabia & 8 & 8 & 8 & 8 & 8 & 8 & 8 & 8 & 8 & 21 & 21 & 19 & 19 \\
\hline & -1.3688 & 0.2663 & 0.2921 & 0.0827 & -1.1641 & 0.3708 & 0.0502 & 0.6493 & 0.5283 & -0.6459 & 1.2957 & -0.0265 & 0.7163 \\
\hline Singapore & 8 & 8 & 8 & 8 & 8 & 8 & 8 & 8 & 8 & 25 & 25 & 22 & 22 \\
\hline & 0.7702 & -1.1082 & 0.0686 & -1.0044 & 1.0622 & 0.8085 & -0.6252 & 0.6137 & 1.5311 & 0.8216 & 0.7516 & -2.0681 & 1.455 \\
\hline South Africa & 7 & 7 & 7 & 7 & 7 & 7 & 7 & 7 & 7 & 24 & 24 & 21 & 21 \\
\hline & 1.5448 & -1.1029 & 0.3178 & 0.8978 & -1.0144 & 0.3962 & 4.5921 & -0.3366 & 19.343 & 0.6123 & 2.3743 & -0.2394 & 4.3899 \\
\hline Switzerland & 8 & 8 & 8 & 8 & 8 & 8 & 8 & 8 & 8 & 25 & 25 & 22 & 22 \\
\hline & -0.1818 & 1.4547 & 0.6202 & 1.2676 & -1.4636 & 2.0217 & -0.1043 & 0.038 & 1.36 & -0.0179 & 0.9514 & -0.145 & 1.1058 \\
\hline Thailand & 8 & 8 & 8 & 8 & 8 & 8 & 8 & 8 & 8 & 25 & 25 & 22 & 22 \\
\hline & 0.764 & 0.987 & 1.478 & 0.6906 & -0.532 & 2.5099 & .5125 & 0.3271 & 1.0023 & -2.791 & 0.4839 & -1.2763 & 1.1311 \\
\hline Turkey & 8 & 8 & 8 & 8 & 8 & 8 & 8 & 8 & 8 & 25 & 25 & 22 & 22 \\
\hline & 2.2203 & -1.8097 & -0.3892 & 1.1012 & -0.1456 & 0.3732 & -0.0451 & 3.9663 & -0.6411 & 0.0742 & -0.0375 & 0.9703 & -0.5654 \\
\hline U.K. & 8 & 8 & 8 & 8 & 8 & 8 & 8 & 8 & 8 & 25 & 25 & 22 & 22 \\
\hline & 1.324 & 0.043 & 0.174 & .959 & 0.179 & 0.7728 & 5242 & -1.028 & 0.8728 & 0.2708 & 2.136 & 1.1064 & 2.0691 \\
\hline Ukraine & 7 & 7 & 7 & 7 & 7 & 7 & 7 & 7 & 7 & 15 & 15 & 12 & 12 \\
\hline & 1.8862 & 1.0742 & 0.3745 & 0.8486 & -0.6196 & 1.1273 & 0.8486 & -0.6196 & 1.1273 & -0.5971 & 1.0424 & 1.6439 & 0.7658 \\
\hline
\end{tabular}

\section{The Model}

The model to explain economic growth

$$
Y_{t}=\alpha+\beta_{1} x_{1}+\beta_{2} x_{2}+\beta_{3} x_{3}+\varepsilon
$$


with

$$
\begin{gathered}
\mathrm{Yt}=\text { GDP growth as a percent for year } \mathrm{t} \\
\mathrm{x}_{1 \mathrm{t}}=\mathrm{FDI} / \mathrm{GDP} \text { lagged } 1 \text { year, } 2 \text { years, } 3 \text { years } \\
\mathrm{x}_{2 \mathrm{t}}=\mathrm{FPI} / \mathrm{GDP} \text { lagged } 1 \text { year, } 2 \text { years, } 3 \text { years } \\
\mathrm{x}_{3 \mathrm{t}}=\text { stock market capitalization/GDP } \\
\varepsilon=\text { Error term }
\end{gathered}
$$

We tried the following variations of the general specification:

$$
\begin{gathered}
\text { Models } 1-3 \\
\mathrm{Y}=\text { GDP Growth } \% \\
\mathrm{X}_{1}=\text { FDI } / \text { GDP lagged }(1,2,3) \text { years } \\
\mathrm{X}_{2}=\text { FPI/GDP lagged }(1,2,3) \text { years } \\
\mathrm{X}_{3}=\text { Stock Market Cap/GDP } \\
\text { Model } 4 \\
\mathrm{Y}=\text { GDP Growth } \% \\
\mathrm{X}_{1}=\text { FDI } / \text { GDP no lag } \\
\mathrm{X}_{2}=\text { Stock Market Cap/GDP } \\
\text { Model } 5 \\
\text { Y }=\text { GDP Growth \% } \\
\mathrm{X}_{1}=\text { FDI/GDP lagged } 3 \text { years } \\
\mathrm{X}_{2}=\text { Stock Market Cap/GDP }
\end{gathered}
$$

We specified models with lags, to see if FDI would raise GDP growth the next year, two years later, or three years later. We also tried using GDP growth to explain FDI for the same year, for the following year, and for two years later. We tried using FDI and increases in stock market capitalization to explain GDP growth. We abandoned our attempt to use FDI as a percentage of GDP to explain increases in export diversification. There were not enough data points to give meaningful results.

$$
\begin{gathered}
\mathrm{y}=\alpha+\beta 1 \mathrm{x} 1+\text { error } \\
\text { where } \mathrm{y}=\text { export growth } \\
\mathrm{x} 1=\mathrm{FDI} / \mathrm{GDP} \text { lagged } 1 \text { year, } 2 \text { years, } 3 \text { years } \\
\text { and similar for index of export diversification }
\end{gathered}
$$

As a further attempt to obtain as much as possible from the data, we also tested cross-country specifications. In these, we used all 33 countries in our sample, and tried to find a relationship between increases in FDI and subsequent increases in GDP growth. We also added foreign portfolio investment and found that the combination of FDI and FPI gave better results. To test whether capital market growth can explain subsequent GDP growth, we included Stock Market Capitalization/ GDP as an explanatory variable. The specifications that we used are of the form

$$
\text { GDP i,t }=\alpha \mathrm{i}, \mathrm{t}+\beta 1 \mathrm{i}, \mathrm{t} \quad \mathrm{x} 1 \mathrm{i}, \mathrm{t}+\beta 2 \times 2 \mathrm{i}, \mathrm{t} \quad++\beta 3 \times 3 \mathrm{i}, \mathrm{t} \text { error }
$$

where $i$ is the country and

$$
\begin{gathered}
\mathrm{t} \text { is the year } \\
\mathrm{x} 1 \text { is FDI, } \\
\mathrm{x} 2 \text { is FPI, and }
\end{gathered}
$$

$\mathrm{x} 3$ is stock market capitalization as a percent of GDP

\section{Results}

With a few exceptions, all the results were weak. Most of the coefficients that we computed were not significantly different from zero. The exceptions were as follows: For India, increases in FDI as a percentage of GDP did correlate 
strongly with increases in GDP in the same year, in the following year, and also two years later.

Stock market capitalization as a percent of GDP explains growth of GDP for most of the countries we studied. Those results were strong. The $t$ statistics came out above 2 , and one of the $t$ statistics came out above 3 . That is interesting, because there are no more than 24 annual data points for stock market capitalization for any of the countries we studied.

For the cross-country regressions, it is to be expected that some of the parameters would be significantly different from zero, because there were so many more degrees of freedom. Nevertheless, the results were similarly inconclusive. For example, when we added foreign portfolio investment and foreign direct investment, we found that large increases in FDI plus FPI were associated with increases in GDP growth for the same year, but not for the next year, and not for the year after that! A cynic might say that an increase in investment increases metrics of economic activity while the investment is going on, even if the investment is unproductive in the longer term. We do not endorse that view, but instead offer explanations in a later section.

\subsection{Discussion of Results}

For the time period and the countries selected, the results were surprisingly weak. Increases in FDI did not precede increases in GDP growth rates except in the case of India. There were a few cases, and a few time periods, where the increase in FDI preceded an uptick in the GDP growth rate, but there were not many more cases than would be expected due to chance.

FDI did have some influence in raising and diversifying exports, but not much. This was surprising because we expected that FDI might lead to raising exports, to diversifying exports, or both.

The data about stock market growth, though much less complete, appeared to be more closely associated with increases in GDP growth. The results were strong for Brazil, India and Mexico. Results for several other countries were also strong enough meriting further study.

We do not assert any causal link between growth of stock market capitalization and growth of the broad economy. Both might be due to an underlying cause that raised both of them, or might be due to exogenous influence. To speculate, institutional reforms happened and the metrics we observed are partly due to that.

For the cross-country regressions, stock market capitalization did have explanatory power, and the results were broadly consistent with the single-country regression results. But the data were not as complete as the data about FDI or GDP growth, so we did not find additional interesting patterns by using the cross-country approach.

\subsection{Proposed Explanations}

There are many possible explanations why the influence of FDI appears to be so slight. We propose the following explanations. They can be grouped into explanations why FDI does not raise economic growth, and explanations why the data do not show a link, even though a link exists.

First, the agnostic explanations:

1. FDI does not add to national savings of the recipient country. Instead it provides the foreign exchange that local rich people acquire and take out of the country to invest in safe havens like Switzerland. This explanation assumes that national savings rates are higher than reported. Local rich and middle class people understate their income, and also understate their saving. They channel only a part of their saving through the national financial system of their country. They earn their unreported savings in local currency cash, and then convert the local currency cash into foreign currency, and send it abroad for deposit into accounts outside their home countries. When FDI comes in, local people who want to buy foreign exchange are able to acquire foreign exchange, and then send it abroad. According to this explanation, FDI adds to the supply of foreign exchange, and makes capital flight more feasible and less expensive.

2. FDI does not add to the economic growth rate of the recipient country because the foreign investment projects do not really cost as much as the data indicate. Instead the foreign capital equipment is overpriced. The over invoicing is an avenue that local rich or corrupt individuals use to obtain foreign exchange and send it out of the country.

3. The FDI does not add to the economic growth rate of the recipient country because the capital equipment is often inappropriate for its stated use. Instead it is worn out, and was fully depreciated before being transferred at an artificially high price to the FDI project. Its foreign owner, usually a multinational, sells it to a tax haven subsidiary, and then marks it up to a much higher price and sells it to the project. In this case the local rich people are not the primary beneficiaries. The foreign owner of the equipment is the beneficiary. The foreign owner is allowed to register the capital equipment at its inflated value. That inflated value then becomes part of the cost basis of the foreign direct investment project. Using that inflated value, the multinational then has high annual depreciation expenses, which cause it to show "losses" in its foreign operations, and those accounting losses shield the multinational from taxes.

Second, the explanations why the data do not show a link, although a link may exist: 
1. In every country there is unreported economic activity, and there is also economic activity that is accurately measured and reported. It is possible that some FDI projects raise unreported economic activity, and do not raise reported economic activity to the same extent. A numerical illustration will show that economic growth would appear not to change when in reality it did increase. Suppose that before a large FDI project comes in, GDP was 1000 and real growth was $3 \%$ per year. The proportion of unreported activity was $25 \%$, so reported GDP was 750 . Real growth was not distributed in the same proportion. In the informal sector real growth was 5\% per year and in the formal sector real growth was $2.33 \%$. That is, GDP of 250 in the informal sector was on track to increase to 262.5 and GDP in the formal sector was on track to increase to 767.5. An observer who can somehow calibrate GDP and real growth correctly, including the informal activity, would state that before an FDI project comes in, GDP was 1000, rising to 1030. An observer who only sees reported data would say that GDP was 750, rising to 767.5.

Then a large FDI project comes in. To illustrate the possible distortion, assume that the FDI project is large, and is accurately reported. The project consists of a one-time investment of 100, i.e., 10\% of total GDP and $13.3 \%$ of reported GDP. The FDI project involves construction, so the foreign investor contracts with a local construction firm. The local construction firm subcontracts with smaller local construction firms that use laborers who are not on formal payrolls. The laborers do not report their wages, or underreport their wages. The laborers spend their underreported wages at small retail shops who underreport their sales and evade taxes. A possible result is that informal economic activity grows and formal economic activity does not grow as much. If informal activity grows $9 \%$ and formal activity grows at its previous rate of $2.33 \%$, then GDP would rise from 1000 to 1040 instead of 1030 , i.e., $4 \%$ instead of 3\%. But formal economic activity would rise only $2.33 \%$ because the increase in economic activity would occur in the informal sector. The informal sector activity would rise from $25 \%$ of total GDP to $26.2 \%$. In this example, the FDI project clearly increases economic growth, but the reported statistics would not show the growth.

2. The FDI project might increase economic growth but underreporting of exports might conceal the increase. Export volumes can be underreported and so can the prices of the goods exported. This is accomplished by double invoicing -the exporter obtains a fraudulent bill of lading, and then ships more merchandise than the bill of lading indicates. The exporter sends the true invoice to the foreign buyer, and shows an invoice for the underreported amount to the Central Bank. Via that ruse, the exporter hands over less of the foreign exchange to the Central Bank. The less the Central Bank gets, the more the exporter can sell in the informal foreign exchange market, obtaining much more local currency than he would if the true amounts were reported. The incentive to underreport grows stronger as the finances of the national governments weaken. For that reason underreporting might be greater in one year and in a different year the official data might coincide more closely to the true amounts exported.

3. The FDI might have been overvalued relative to its true contribution to the local economy. Its overvaluation might be due to a naive but sincere attempt to put into use hardware that is wrong for the application; or it might be due to a tax motivation, to overvalue the asset and then deduct depreciation each year. It might also be due to a malicious intent to defraud the national government. The equipment that is sent did not always cost the amount shown on the shipping documents. It might have cost much less.

\section{Conclusion}

It is time to reassess the importance of FDI as a macroeconomic aggregate that it worth watching. And the heated, centuries-old debate about the merits of FDI might fade into the archives of history. It would march down into the annals alongside many other contentious debates that have lost their grip on mainstream thinking.

\section{References}

Buckley, P. J. (1982). Multinational Enterprises and Economic Analysis, Cambridge University Press, London.

Buckley, P. J. (1988). The limits of explanation: testing the internatisation theory of the multinational. Journal of International Business Studies, 19, 181-93.

Buckley, P. J., \& Casson, M. (1976). The Future of the Multinational Enterprise, Holmes and Meier, London.

Buckley, P. J., \& Casson, M. (1985). The Economic Analysis of the Multinational Enterprise: Selected Papers, Macmillan, London.

Buckley, P. J., Devinney, M. T., \& Louviere, J. J. (2007). Do managers behave the way theory suggests? A choice-theoretic examination of foreign direct investment location decision-making." Journal of International Business Studies, 38, 1069-1094.

Davidson, W. (1980). The Location of Foreign Direct Investment Activity: Country Characteristics and Experience Effects., Journal of International Business Studies, 11-2, 9-22.

Dunning, J. H. (1980). Toward an eclectic theory of international production: Some empirical tests", Journal of International Business Studies, 11(1), 9-31. 
Dunning, J. H. (1988). The eclectic paradigm of international production: A restatement and some possible extensions", Journal of International Business Studies, Spring.

Fayerweather, J. (1982). International Business Strategy and Administration, Ballinger, Cambridge, MA.

Hecksher, E., \& Ohlin, B. (1933). Interregional and International Trade, Harvard University Press, Cambridge, MA.

Hymer, S. (1970). The efficiency (contradictions) of multinational corporations, American Economic Review, 60, 441-8.

Hymer, S. H. (1976). The International Operations of Firms: A Study of Foreign Direct Investment, Cambridge, MA: MIT Press.

International Monetary Fund. (2003). Foreign Direct Investment Trends and Statistics, (Washington).

Johanson, J., \& Jan-Erik, V. (1977). The internationalization process of the firm - A model of knowledge and development and increasing foreign market commitments. Journal of International Business Studies, 8, 22-32.

Kindleberger, C. P. (1969). American Business Abroad: Six Lectures on Direct Investment, New Haven, Yale University Press.

Kwok, C. C. Y., \& Reeb, D. (2000). Internationalization and Firm Risk: An Upstream-Downstream Hypothesis, Journal of International Business Studies, 31(4), 611-629.

Lee, K., \& Chuck, K. (1988). Multinational corporations vs. domestic corporations: International environmental factors and determinants of capital structure. Journal of International Business Studies.

Lessard, D. R., \& Williamson, J. (1987). Capital Flight and Third World Debt. Washington, D.C.: Institute for International Economics.

Lessard, D. R., \& Williamson, J. (1987). Capital Flight: The problem and policy responses. Washington, DC: Institute for International Economics.

Makino, S., \& Neupert, K. E. (2000). National Culture, Transaction Costs and the Choice Between Joint Venture and Wholly Owned Subsidiary, Journal of International Business Studies, 31(4).

Morgan, R. E., \& Katsikeas, C. S. (1997). Theories of International Trade, Foreign Direct Investment and Firm Internationalization: A Critique, Management Decision, 68-78.

O’Grady, S., \& Lane, H. W. (1996). The Psychic Distance Paradox, Journal of International Business Studies, Second Quarter, 309-333.

Porter, M. (1998) Clusters and the New Economics of Competition, Harvard Business Review, Nov-Dec.

Reeb, D., Kwok, C., \& Young, B. H. (1998). Systematic Risk of the Multinational Corporation, Journal of International Business Studies, Second Quarter 1998.

Ricardo, D. (1817). "Principles of political economy" in Saffra, P. (Ed.) (1951). The Works and Correspondence of David Ricardo, 1. Cambridge University Press, London.

Shaked, I. (1986). Are Multinational Corporations Safer?, Journal of International Business Studies, Spring.

Shapiro, Alan (1992). Multinational Financial Management, Boston, Mass: Allyn and Bacon.

Smith, A. (1776). An Inquiry into the Nature and Causes of the Wealth of Nations, edited by E. Cannan (1961) and reprinted in Methuen, London.

UNCTAD World Investment Report (2003). FDI Policies for Development: National and International Perspective New York and Geneva: United Nations.

UNCTAD. (2003). "FDI and development: Policy issues related to the growth of FDI in services" New York and Geneva: United Nations.

Vernon, R. (1966). International investment and international trade in the product cycle, Quarterly Journal of Economics, 190-207.

Vernon, R. (1971). Sovereignty at Bay, Basic Books, New York, NY.

Wells, L. T. (1968). A product life cycle for international trade, Journal of Marketing, 33, 1-6.

Wells, L. T. (1969). Test of a product cycle model of international trade, Quarterly Journal of Economics, February, $152-62$.

\section{(cc) EY}

This work is licensed under a Creative Commons Attribution 3.0 License 